\title{
6
}

\section{Legal and Ontological Pluralism: Recognising Rivers as More- Than-Human Entities}

Around the world, many peoples and societies are contending with the trials of creating and applying apparatuses recognise Indigenous interests and authority within freshwater governance and management (Berry et al. 2018; Castleden et al. 2017; Cosens and Chaffin 2016; Curran 2019; Jackson 2018; Muru-Lanning 2016a; Ruru 2018a; Wilson 2019). Many new policies and strategies specifically acknowledge the rights of Indigenous peoples, their interests in and values they attached to specific geo-regions (be it rivers, lakes, or forests) and environmental resources, including flora and fauna, and take the form of new legal agreements which are directed at reconciling diverse worldviews, values, and ways of life within particular environments (Daigle 2016; Johnston 2018; Nursey-Bray and Palmer 2018; Premauer and Berkes 2015). However, across the settler societies (including Aotearoa, Australia, USA and Canada) there are no consistent approaches to Indigenous freshwater governance and management being adopted to honour water resource agreements between Indigenous nations and settler-states or resolve Indigenous environmental injustices.

In this chapter we explore the ways in which the formal recognition (to some extent) of Indigenous knowledge systems within environmental 
governance and the role of reconcilition in achieving environmental justice. We draw on McGregor's definition of reconcilation conceptualised as going beyond "the human dimension to include 'relationships with the Earth and all living beings"' (McGregor et al. 2020, p. 9).

In Aotearoa, tikanga (Māori legal order) are receiving greater focus amongst scholars, legal practitioners, and activists, with mātauranga and tikanga are increasingly recognised for holding practical methods for achieving justice for Māori. We examine whether recent agreements between the New Zealand Crown (Crown) and Māori tribal groups (iwi), known as Treaty 'settlements', to establish shared co-governance and management over rivers encapsulate and are capable of achieving environmental justice (as defined with Māori ontologies and epistemologies). In this chapter, more broadly, we explore how legal and ontological pluralism, amongst scholars as well as law- and policy-makers in Aotearoa and other (post)colonial contexts, can address environmental injustices. Rather than seek to provide a singular definition of Indigenous environmental justice (IEJ), we instead examine how Indigenous peoples are engaged in efforts to negotiate with and challenge the colonial legal orders, develop their laws, policies, and governance frameworks to achieve justice within the freshwater realm.

The structure of the chapter is as follows. First, we provide very brief overview of how respect for Indigenous ontologies and epsitemologies is a critical component of IEJ. Second, we discuss tikanga Māori (the laws of Māori) and the ways in which the settler-nation deliberately sought to exclude and supplant tikanga for more than a century. We emphasis that Aotearoa's exclusionary policies and legal processes were not unique but rather were a feature of settler colonalism around the globe. Third, we examine the emergence of legal pluralism in settler-colonial and formercolonial societies wherein legal traditions (based on different ontologies) are being incorporated laws and institutional arrangements. Fourth, we chart how increased to recognise Te Tiriti o Waitangi/the Treaty of Waitangi and the development of formal reconciliation processes between iwi (Māori tribes) and the Crown (Aotearoa New Zealand's Central Government) as fostering the development of new agreements and legislation founded on legal and ontological pluralism. Lastly, we analyse legislation that recognising tikanga (to some extent) and mātauranga 
(knowleddge) regarding how two rivers (Waipā and Whanganui) are governed and managed, and draw attention the stregnthens and weaknesses of the new laws for achieving IEJ.

\section{Indigenous Knowledge, Laws, and Worldviews}

Despite being focused on Indigenous peoples' lives, livelihoods, lands and waters, much of the existing scholarship on Indigenous injustice are not situated within Indigneous worldviews, epistemologies, and methodologically (Muir and Booth 2012; Shah and Rodina 2018; Vickery and Hunter 2016; Zwarteveen and Boelens 2014). Yet, as we articulate throughout this book, Indigenous theories, ontologies, epistemologies, and methodologies can inform discussions of what is IEJ and how it can be achieved. The argument builds on international scholars emerging within Indigenous research more broadly, in which Indigenous knowledge systems, philosophies, and legal systems are the building blocks for inquiries (McGregor 2018; Watene 2016; Whyte 2018; Winter 2019). Such approaches are intended to address the "lack of consideration and respect" shown for Indigenous intellectual traditions (Hunt 2014, p. 29).

One of the key features of Indigenous peoples' worldviews or ontologies (despite incredible diversity in cultural, linguistic, political, economic, historical and geographical contexts) is their conceptualisation of people being in relationships with 'more-than-humans' or 'other orders of beings' (Bergman 2006; McGregor 2018; Watene 2016; Whyte 2018; Winter 2019). The importance of these relationships are highlighted in how Indigenous peoples' conceptualisations of justice extend to include the "more-than-human world" (McGregor 2018; Salmond 2018). Indigenous systems of knowledge are premised on a set of assumptions (ontological, epistemological and metaphysical) about humanity's position in the world. Furthermore, these assumptions about how the world (or worlds) and all beings within it/them also conveyed key principles that underpin Indigenous laws and governance systems, including giving directions about how people should act in regard to others (including rivers, plants, and animals). 
There is not a singular and universal Māori worldview, but rather a pluralities of ways of thinking, reflective partly of the localised and placebased nature of Māori iwi (tribal) groupings. Instead, scholars talk broadly of the ontologies and epistemologies encapsulated within the term Te Ao Māori (the world of Māori) as distinct from Te Ao Pākehā (the world of Pākehā aka the settler world). Te Ao Māori is characterised by nonlinearity and relationships based on relationality and reciprocity between humans and non-humans (including metaphysical beings). Tikanga (laws) — which includes principles and values - are produced and sustained by rūnanga (tribal councils), iwi, hapū (sub-tribe), and whanau (extended family) (Salmond 2017; Thompson-Fawcett et al. 2017). Tikanga and principles are the foundations of iwi identities, duties, obligations and rights of individuals, whānau (family, extended family), hapū, iwi, and rūnanga. Māori identify themselves through their genealogical (whakapapa) connections and affiliated to whānau, hapū and iwi, but also to particular lands (whenua), mountains (maunga), rivers (awa) and seas (moana). These whakapapa relationships inextricably bind them (as kin) to their environment (taiao) encompassing all elements including rivers (awa) and land (whenua); as humans and more-than-humans (accordingly to Māori cosmology) alike are all descendants from Papatūānuku (Earth Mother) and Ranginui (Sky Father) (Harmsworth et al. 2016; Ruru 2013; Salmond 2017). Mātauranga Māori (Māori system of knowledge) is premised on this relational ontology, wherein awa are the living embodiment of whakapapa, the mana (prestige, power and sovereignty) of hapū and iwi, and possess their own distinct mauri (life force) and spiritual veracity (wairua), as well as their own agency (Whaanga et al. 2018). Explorations of such ideas highlight the ways in which Indigenous environmental injustices differ from those encountered by non-Indigenous peoples, and also demonstrate that efforts to achieve IEJ rests in actions that attend to the interwoven wellbeing of human and more-than-human beings. 


\section{Tikanga Māori: The First Legal Order of Aotearoa}

Māori ways of thinking and being in their world, based on responsibilities of care for their more-than-human relatives, underpinned the laws (tikanga) and governance systems of Māori. Tikanga refers to traditions, protocols and laws that regulated behaviour within Māori iwi, hapū and whānau. These laws were (and are still) embedded in sources and practices including: (1) whanaungatanga (extended family, responsibilities, relationships, the centrality of kinship, whakapapa that binds the Māori world together); (2) mana (power, authority, control, prestige, power contributing to leadership); (3) tapu (respect, scared, forbidden) and its opposite noa (normal, ordinary) that pays different roles including social (keeping people safe), political (ceremony, leadership), spiritual (wairua/ spiritual integrity); (4) utu (retaliation and retribution); (5) kaitiakitanga (guardianship over environment, taking care of one's more-than-human kin). Tikanga, therefore, is premised on the need to maintain the balance between all things and thereby ensuring the protection and enhancement of mauri and wairua of human and more-than-human beings both now and in the future.

In terms of the contrast between British (and then settler colonial) legal order and tikanga Māori, Justice Eddie Durie underlined how Western law is rules-based (literate) whereas tikanga is governed by values which the community subscribed to (Durie 1994). While Euro-Western cultures generally ascribe to a clear distinction between law and mortality, tikanga Māori is rules, practices, values, and ethics based (Durie 1994, p. 3). Metge observed, however, that "Western laws are also values-based; the values concerned being interpreted by the law makers" (Metge 1997, p. 5). Mulgan added: "All law, Pākehā as well as Māori, arises out of social norms and the need to enforce these norms within society. The ultimate source of Pākehā law is not the courts or statutes but the social values reflected by Parliament by statutes and by judges in their decisions" (Mulgan 1997, p. 2). Metge concluded that the primary difference between tikanga Māori and settler legal order originates in the different sources and modes of communication (Metge 1997). Tikanga emerges 
"out of on-going community debate and practice and are communicated orally" and as a consequence "they are adapted to changing circumstances easily, quickly and without most people being consciously aware of the shift" (Metge 1997). In contrast, Western (settler) laws are "formulated and codified by a formal law-making body and are published in print; their amendment, while possible, is a complex and lengthy process" (Metge 1997). Yet, all societies possess laws that represent certain values and fulfil particular functions within society, most notably the preservation of social order and maintenance of collective security. Law is abided in diverse societies because individuals and communities obey the law (on the basis that they believe that the law is just, they seek protection from the law, or they fear sanctions as a consequence of non-observance) (Jones 2016; McGregor 2018).

Tikanga Māori was the legal order that operated in Aotearoa prior to Pākehā colonisation and continued to operate in various ways despite colonial efforts to denigrate and suppress it in the nineteenth and twentieth centuries (Dorsett 2017; Ruru 2009, 2012). For instance, the settler-state disregarded Māori laws about how waste products should be disposed of (as outlined in Chap. 3) and discharged human waste directly into waterways; as we describe in Chap. 6, this practice breached tikanga and caused negative impacts to the health of the wai (water) and its human and more-than-human beings whose mauri was intertwined with. The establishment of Aotearoa's legal order (which was heavily informed by that of Britain) and the ways in which tikanga Māori was disregarded and excluded parallels what happened in other colonial contexts.

Within the borders of the settler colonial states of Aotearoa, United States, Australia, and Canada_-boundaries often newly defined with limited attention to existing Indigenous territories, governance regimes or practices-non-colonial state Indigenous law was assigned subordinate status to 'official' settler state law imposed by settler-colonial powers (Green and Hendry 2019; Hendry and Tatum 2018; Robinson and Graham 2018). Such a characterisation of Indigenous nations and legal orders as non-state were significant. The denial of Indigenous legal orders the standing of 'law' helped to facilitate the Indigenous laws being marginalised and suppressed on the basis of being 'mere' traditions or customs (Green and Hendry 2019), and also labelled such legal systems 
(such as tikanga) as unofficial and unworthy of the attention of legal scholars and practitioners. The work of recent non-positivist legal scholars is motivated at counteracting this negative framing by portraying Indigenous legal orders (qua law) as not only worthy of respect but more significantly as equal status of the legal orders of settler-states (Green and Hendry 2019, p. 10). For Margaret Davies, critical legal pluralism is about legal pluralities more broadly, not simply in the context of legal pluralism but a diversity of legal theory; a strategy focused on debunking the principle that "there is either an objective or true version of legal pluralism" (Hendry 2019, p. 171). For Davies, all law is generated through governance practices (Davies 2010; Hendry 2019), whereas for other non-positivist legal scholars, "law is morally entailed by practice" (Green and Hendry 2019, p. 10). Green and Hendry (2019) argue that while a non-positivist framing of law is not always necessary, such a conceptualisation does provide an important "explanatory power in relation to the settler-state legitimacy crises" (Green and Hendry 2019, pp. 10-11).

Scholars are increasingly focusing on how legal pluralism can offer new opportunities for transforming legal and governance regimes by challenging the dominant settler-state legal system, allowing for multiple legal systems to simultaneously operate (Indigenous and settler-colonial). For instance, Jones' (2016) exploration of legal pluralism in Aotearoa (consisting of legislation, case laws, and tikanga) provides renewed possibilities for Māori iwi to achieve some form of self-determination and autonomy within the overarching structure of the settler-colonial state (Jones 2016; O’Donnell and Macpherson 2019).

A key part of efforts, over the last three decades, to address Māori injustices involves reforms to Aotearoa NZ's contemporary (settlercolonial-based) legal order to recognise (to some extent) aspects of tikanga. Māori legal scholar Jacinta Ruru calls on Māori lawyers to continue this journey to reconciliation by considering the place of "our first laws_tikanga Māori-as law as part of our complete legal system" present-day (Ruru 2018b). In her research Ruru argues, following from countless other Māori (in their roles as academics, lawyers, leaders and politicians, activists, and members of particular iwi/hapū/whānau), that settler-nations like Aotearoa "need to look for new ways to meaningfully reconcile with Indigenous peoples to displace legal assumptions for 
Crown ownership and the governance of land and water" (Ruru 2018b). Indeed, during the late twentieth and twenty-first centuries, tied to political recognition of the Treaty and the Crown's attempts to reconcile with Māori, there have been ongoing attempts to revive and reassert the applied usefulness of tikanga Māori as a legal order and process and, in doing so, articulate and define a place for that law within the settler-state of Aotearoa's legal system (Jackson 1995, 2007).

Legislation is now requiring that the Crown's legal order incorporate (to a limited degree) aspects of tikanga. The Resource Management Act (1991)) acknowledges that Māori exercise kaitiakitanga (environmental guardianship) and the significance of wāhi tapu (scared sites) and taonga (treasures) in waters and lands. Te Ture Whenua Māori Act 1993 (the Māori Land Act) recognises that a child adopted into a family in accordance with tikanga Māori practices of whāngai (customary adoption within the same hapū) can inherit land interests (from members of their adoptive family). Importantly, the Court of Appeal, in 2020, determined the Crown's allowance of offshore iron sand mining off the coast of Taranaki conflicted with iwi kaitiakitanga practices (Court of Appeal 2020). Likewise, the Supreme Court, in 2012, found that "Māori custom according to tikanga is therefore part of the values of the New Zealand common law" (New Zealand Supreme Court 2013, p. 94). At the forefront of these efforts to include tikanga into settler legal order are the "visions and aspirations of our Māori communities, iwi, whānau, and hapū" (Ruru 2018b). Treaty settlements, which we discuss later in this chapter, are perhaps the place where Māori voices (and their tikanga) are best and most powerfully encapsulated, which are providing the changes to the legal order of Aotearoa.

\section{Limited Recognition: Indigenous Legal Traditions with Settler Legal Order}

Globally a wealth of new legal pluralist research documents efforts to decentre settler-colonial state law and concentrate on legal subjects and their capacities to produce new legal knowledge and implement 
frameworks that comprise their legal subjectivity (Bambridge 2016; Curran 2019; Hendry and Tatum 2018; Jones 2016). In British Columbia Canada, as the work of Curran (2019) and others demonstrate, a wide number of First Nations' are seeking to repoliticise water governance regimes by situating their legal traditions and laws and their expectations about what constitutes free prior and informed consent in the joint water arrangements they hold with the provincial government (Bakker et al. 2018; Curran 2019). Similarly, in the United States, numerous different Indigenous nations are continuing to challenge the settler-state legal order and expand on how "Indians reserved water rights" are defined within state and federal laws (Curran 2019, p. 19). For instance, the judge's decision in the case of Agua Calienta Band of Cahuilla Indians v Coachella Valley District found that the Tribe holds the rights to federal reserved groundwater and also that the Tribe's right to use the water took precedence over the state government of California's water allocation regime (Curran 2019). Likewise, the Standing Rock protest movement, started by Standing Rock Sioux to resist the Dakota Access Pipeline, is a declaration that Indigenous peoples' and their legal orders remain despite the ongoing colonial intrusions and dispossessions, and demand for IEJ (Baum 2019; Gilio-Whitaker 2019; LeQuesne 2019; Whyte 2017).

Researchers observe that destabilising modern politics and the reassertion of Indigenous laws, governance structures, and practices that rupture dominant political configurations are evidence of the wider disruption of hegemonic Western knowledge systems (Blaser et al. 2013, p. 20; Oslender 2019; Wilson 2019; Yates et al. 2017). Recent research investigates approaches, diversely referred to as collaborative and/or integrative models, including joint or co-governance agreements between Indigenous peoples and governments. These approaches seek to recognise (to a greater or lesser extent) Indigenous rights, knowledges and interests in water (as well as lands and seas), and to create processes of sharing responsibilities for decision-making, as well as ways that different parties can co-learn and co-produce new knowledge to improve freshwater management and/ or health (Bischoff-Mattson et al. 2018; Bischoff-Mattson and Lynch 2017; Harmsworth et al. 2016; Memon and Kirk 2012; Wilson 2019). Based on their research in Australia, Howitt and Suchet-Pearson call for "ontological pluralism" whereby the dichotomy discourse and interlinked 
issues are defined and addressed. They argue that this naming and confronting can facilitate frameworks of environmental management scholarship and practical actions founded on mutual respect and plural value systems and enacted in ways that "acknowledges and respects Indigenous ontologies, or ways of being, and at the same time is attentive to the historical and current dominance of Eurocentric thinking within natural resource management" (Howitt and Suchet-Pearson 2006). The support for ontological pluralism (termed by some scholars as the pluriverse) enables possibilities and potentialities to bring about a transformation in freshwater governance and management by supporting Indigenous and hybrid governance structures and practices entrenched within settlercolonial systems of power and control (Blaser 2014; Wilson and Inkster 2018; Yates et al. 2017).

Research from Central and South America similarly demonstrates how different societies (all of which are dealing with ongoing legacies of colonialism) are grappling with recognition of more-than-human sentient entities and Indigenous peoples' ontologies and interests in their ancestral lands and waters through legislation and policies; which attests to the diverse possibilities of ontological and legal pluralism. Under the Ecuadorian Constitution of 2008, for instance, the rights of Nature (Pacha Mama) are recognised. Article 71 refers to the "nature or the Pacha Mama" possessing the right to have its "existence, maintenance and regeneration of vital cycles, structures, functions and evolutionary processes" respected. Pacha Mama also possess the right to legal restoration if any damage to its natural processes occurs. As a consequent of Article 71, any legal person (human and more-than-human) as well as any community (in Ecuador or from elsewhere) can insist that the Ecuadorian government honours and respects such rights. A well-known legal case (the "Vilcabmba River case") saw Nature being named as the plaintiff. The court ruled that Nature did possess rights and ordered the government to restore the riparian ecosystems of the degraded Vilcabmba River (Clark et al. 2018, pp. 796-797). The legal recognition of Pacha Mama resonates with the Andes concept of Buen Vivir vision (living well with the Earth), drawing on Indigenous intellectual traditions and knowledge systems, to demand the ontological and epistemological extension of living well within human communities to be extended to encompass the 
natural world (Cochrane 2014; Samuel 2019). Buen vivir "displaces the centrality of humans as the sole subject endowed with political representation and as the source of all valuation" (Chuji et al. 2019).

Such works' demonstrate the different ways in which such approaches can disrupt taken-for-granted views (the colonial status quo) about what or who has agency and how the world(s) are made and remade (Blaser 2014; Blaser et al. 2013; Chuji et al. 2019; Oslender 2019; Sieder and Barrera 2017). Accordingly, ontological politics are increasingly at the heart of analyses of the connections between multiple ways of thinking (and doing) (Chandler and Reid 2018). Likewise, research from Aotearoa and Australia examines the potential for Indigenous understandings of and engagements with rivers to foster transformations of the ways in which rivers are governed and managed (Bark et al. 2015; BischoffMattson et al. 2018; Weir 2009, p. 119). In Aotearoa, as our next section explores further, this includes research directed at identifying ways of conceptualising rivers (and nature more broadly) that is ontologically and epistemologically inclusive, (as well as pragmatic and equitable) (Charpleix 2018; Salmond et al. 2014; Salmond 2017).

\section{Decolonising Freshwater Governance: (Mis) Recognition of the Treaty and Tikanga}

The significance of the Treaty has been the subject of intense legal and academic debate since it was signed in 1840 by representatives of the British Crown and more than 500 Māori rangatira (chiefs) (Jackson 1993; Orange 2015). Most Treaty scholars now concur that rangatira never intended to cede their sovereignty (absolute authority) over Māori to the Crown, nor did they intend to give up their tikanga (customary laws) and instead entered into a partnership agreement on which ongoing relationships with the British Crown were to be built (Healy et al. 2012; Jackson 1992, 1993; Mutu 2011; Orange 2015). The Treaty was a partnership agreement between the two different cultures and worlds ( $\mathrm{Te}$ Ao Māori and Te Ao Pākehā), which implied (even if it did not explicitly state) that the Crown acknowledged tikanga Māori as the existing legal 
order and that some form of legal pluralism would operate in Aotearoa following the Treaty. However, for most of the nineteenth and twentieth centuries, the Treaty was denigrated (Anderson et al. 2015; Belich 1996, 2013; Ruru et al. 2017).

Soon after its signing, the Treaty, as we discuss in depth in Chaps. 3 and 4, the settler-colonial courts and successive settler-colonial governments did not recognise the Treaty nor acknowledge its legal, constitutional or political significance (Anderson et al. 2015; Belich 1996, 2013; Ruru et al. 2017). The statements made by Chief Justice Sir James Prendergast in 1877, when he issued his judgement in the case of Wi Parata $v$ The Bishop of Wellington (finding in favour of the Bishop of Wellington's claims over a section of Māori land), highlighted broader Pākehā legal and public attitudes towards the Treaty as well as tikanga more generally. Prendergast declared the Treaty "worthless" on the basis it was "between a civilised nation and a group of savages" who were not sufficiently advanced enough to sign a treaty, furthermore since the Treaty was not enshrined into domestic law it was now a "simple nullity". Prendergast's ruling and statements (informed by earlier Court of Appeal decisions) helped shape decision-making on Treaty issues for decades to come and were used to justify the alienation of more and more Māori land (Prendergast 1877).

Since the mid-1970s, however, there has been a significant increase in references to the principles of the Treaty or to specific rights and interests within legislation, which represents an important shift in recognising the legitimacy and authority of Maori in a range of contexts. Since 1975, many laws in Aotearoa make reference to Treaty principles (Jones 2016; Waitangi Tribunal 1999, 2018). The first legislation to do so was the Treaty of Waitangi Act (1975). Since that legislation, many other government policies, laws, Waitangi Tribunal reports, and court cases make reference to the Treaty principles; however, there is no final or complete list of what those principles are and the principles are not codified in any laws. Instead, official government documents refer to the Treaty principles in vague terms, without any reference to the actual treaty text (be it the English or Māori version of the treaty). In 1989, the Fourth Labour government became the first central government to outline Treaty principles to guide its actions with regards to its relationships with Māori: (1) 
The Crown (central government) possesses the right to govern and make laws; (2) Māori iwi possess the right to organise as iwi, and are legally able (through laws) to control their resources; (3) Legal equality (that all New Zealanders are equal under the laws); (4) The Crown and iwi are obliged to interact with each other with a reasonable level of cooperation on major issues that are of collective concern; (5) The Crown is responsible for providing effective institutional processes for the resolution of Māori grievances in the expectation that reconciliation can occur (Jones 2016; Palmer 1989). However, no later central government in Aotearoa defined any new Treaty principles, and the principles are at best vague ideas that governments are meant to follow rather than laws.

Within Aotearoa’s (settler-colonial) legal order, Māori hold no general constitutional rights that give them special legal recognition as Indigenous people or as Treaty partners (under Tiriti o Waitangi/Treaty of Waitangi hereafter the Treaty) and allows them to be heard in a court setting (Jones 2016; Ruru 2012). Partly, because the country does not possess a specific written constitution that explicitly acknowledges Mãori interests. The Treaty is still not part of the country's domestic law. The Treaty is now commonly referred to by legal scholars as the "informal constitution along with the New Zealand Bill of Rights Act 1990 and the Constitution Act 1986" (Ruru 2012, p. 112). For members of the Aotearoa judiciary and those acting under the law, the Treaty itself is only relevant when explicitly included within statutes. Thus, while Article Two of the Treaty guarantee to Māori that they would retain their tino rangatiratanga (authority) over to their whenua (land) and other taonga (treasures) including rivers (while agreeing to give the Crown kawantantanga/governorship over Aotearoa), the lack of legal recognition of the Treaty or attempts to explicitly articulate the Treaty principles (discussed in the next section) into laws means that Māori still lack constitutional rights to water. Nevertheless, there is a small degree of domestic legal acknowledgement of the relationships of Māori with water. For instance, the Resource Management Act (RMA 1991) requires local authorities to recognise the relationships of Māori with their ancestral waterbodies (rivers, lakes, seas) and take into account kaitiakitanga (environmental guardianship exercised by Māori) when exercising their functions and powers to managing the development, use, and protection of environments (Bargh 
2020; Bell 2018; Ruru 2012). However, the RMA, as we detailed in our previous chapter, only provides a limited degree of recognition to Māori interests in water, and gives them the right to be included in local government decision-making regarding management and use of water, which is to say participatory inclusion. Yet, Māori lack the authority to shape and make decisions about their waterways (which is at the heart of Māori demands dating back to their signing of the Treaty which guarantee to them that their rangatiratanga would be preserved and protected by the Crown).

While Māori (and any other person in Aotearoa) can appeal decisions relating to resource consents (issued under the RMA) to the Environment Court, these appeals are restricted to matters of law (Ruru 2012). There are numerous instances where Māori objectors (such as Greensill and members of her hapū Tainui discussed in Chap. 5) appeals of regional and district council decisions about resource consents to discharge wastewater, take water, or dam water. In the majority of these legal cases Māori emphasise how water, specifically their ancestral rivers (their awa), underpin their cultural identity (through their whakapapa), their belief that all water possesses a mauri and the significance of waterbodies as food harvesting sites. Yet, in most instances Māori do not come out of the courts as victors, and many lose their cases outright. The courts, while aware of Māori relationships to awa, wai, and whenua, argue that section 6(e) of the RMA does not give Māori the right to veto resource consents or other decisions of local government, but merely the right to participate in decision-making processes (Greensill 2010; Ruru 2012, 2018a). The judiciary interpretations, however, clashes with those of Māori who for generations have been protesting for their rangatiratanga to be recognised, respected and honoured by the Crown; the views of Māori are recently endorsed by the findings of the Waitangi Tribunal.

In 1975, the Waitangi Tribunal was established as a permanent commission of inquiry to investigate Māori claims that the Crown was not honouring the terms of the Treaty of Waitangi. The responsibilities of the 
Tribunal include researching and holding public inquiries into historic and contemporary claims filed by any Māori individual or group that the Crown breached the Treaty, reporting back to claimants and the Crown as to its inquiry findings, and making recommendations to the Crown as to how it can address Treaty breaches (reconciliation and restorative justice) (Jones 2016; Mutu 2018, 2019; Wheen and Hayward 2012). Each Waitangi Tribunal inquiry into Māori claims is required to determine whether a Crown action (or omission) was or is inconsistent with the Treaty principles (as which recently occurred with its Wai 898 inquiry into Te Rohe Pōtae). Each Tribunal panel, which always comprises Tribunal members including a Māori Land Court judge, a historian, a kaumatua, are required to determine not only if the Crown breached the Treaty principles, but also which principles apply for each claims being investigated. For this reason, the Tribunal does not keep a singular set of unchanging Treaty principles that it applies for each claim before it (highlighting the different experiences of iwi). Indeed, in 1983, the Waitangi Tribunal stated "The spirit of the Treaty transcends the sum total of its component written words and puts literal and narrow interpretations out of place" (Waitangi Tribunal 1983, p. 47). Over the decades since 1975, however, some key principles emerged from Tribunal reports that are often applied in various claims. These principles are derived not only from the terms of the Treaty's two texts (Māori and English language versions), but also from the socio-cultural and political circumstances in which the Treaty was created and signed by (some) Māori and representatives of the British Crown in 1840. To illustrate the Waitangi Tribunal approach to the Treaty principles we refer attention to the Waitangi Tribunal's inquiry into Te Rohe Pōtae (King Country) (Waitangi Tribunal 2018). We stress that the Treaty principles are those that Te Rohe Pottae Tribunal viewed were relevant to that inquiry and differ from those applied to other inquiries. 
Waitangi Tribunal's approach to Treaty principles: Te Rohe Pōtae Inquiry

\begin{tabular}{|c|c|}
\hline Treaty Principle & Interpretation of the principle \\
\hline $\begin{array}{l}\text { Tino rangatiratanga, } \\
\text { self-government and } \\
\text { autonomy }\end{array}$ & $\begin{array}{l}\text { Māori communities retained their tino rangatiratanga } \\
\text { (under Article Two of the Treaty), which included } \\
\text { their right to self-government and autonomy, "and } \\
\text { their right to manage the full range of their affairs in } \\
\text { accordance with their own tikanga" (Waitangi } \\
\text { Tribunal 2018, p. 189). As part of the Treaty } \\
\text { exchange, which included mutual recognition of } \\
\text { kāwanatanga and tino rangatiratanga, the Crown } \\
\text { guarantees to protect and provide for Māori } \\
\text { autonomy and authority. Autonomy, was defined } \\
\text { previously by the Turanga Tribunal as 'the ability of } \\
\text { tribal communities to govern themselves as they had } \\
\text { for centuries, to determine their own internal } \\
\text { political, economic, and social rights and objectives, } \\
\text { and to act collectively in accordance with those } \\
\text { determinants'. }\end{array}$ \\
\hline $\begin{array}{l}\text { Kāwanatanga and } \\
\text { good governance }\end{array}$ & $\begin{array}{l}\text { The Crown possess the right to govern and make laws, } \\
\text { which was first (in the decades post-1840) for the } \\
\text { purpose of controlling settlers and settlement and } \\
\text { regulating relationships with foreign powers. The } \\
\text { power of kāwanatanga (governance), however, is } \\
\text { qualified by the rights that continued to be reserved } \\
\text { to Māori (under Article Two of the Treaty). "To the } \\
\text { extent that it affects Māori communities, the right of } \\
\text { kāwanatanga must be used to protect Māori } \\
\text { interests" (Waitangi Tribunal 2018, p. 189). Related to } \\
\text { kāwanatanga, the Crown is required to ensure it acts } \\
\text { in accordance with its own laws, be held to account } \\
\text { for its actions to Māori, and be subjected to } \\
\text { independent scrutiny where appropriate. }\end{array}$ \\
\hline Partnership & $\begin{array}{l}\text { The Treaty created a relationship that was dependent } \\
\text { on ongoing dialogue and negotiation, under which } \\
\text { Māori and the Crown would work together to agree } \\
\text { to the practical details of how tino rangatiratanga } \\
\text { and kāwanatanga would co-exist. Both Treaty } \\
\text { partners were duty bound to act honourably and in } \\
\text { good faith with each other. The obligations of this } \\
\text { partnership meant that neither partner can act in a } \\
\text { way that "affects the other's sphere of influence } \\
\text { without their consent" (Waitangi Tribunal 2018, } \\
\text { p. 189), it also created a duty that the Crown consult } \\
\text { with Māori and obtain free and informed consent } \\
\text { from iwi before land and water management. }\end{array}$ \\
\hline
\end{tabular}


(continued)

\begin{tabular}{ll}
\hline Treaty Principle & Interpretation of the principle \\
\hline Reciprocity and & Above all, the Treaty provided the basis on which two \\
mutual benefit: & peoples (Māori and Pākehā) could share one country. \\
It centred on reciprocal partnership relations that & were (and still are) one that involved the exchanges \\
& for mutual benefits and advantages between the \\
& Crown and Māori. Māori granted the Crown the new \\
& power of kāwanatanga (governance) in return for a \\
& guarantee that the protection of their tino \\
& rangatiratanga over their land, people, and taonga \\
& would be safeguarded. Through this recognition of \\
& different powers, the Treaty was intended to provide \\
& for the mutual protection of both Te Ao Māori and Te \\
& Ao Pākehā. Accordingly, it was meant to ensure that \\
& relationships between Māori and Pākehā peoples \\
& would provide mutual advantages for both cultures. \\
The Crown are obligated to employ its power of & kāwanatanga to actively protect the interests and \\
Active protection of Māori rights (as guaranteed under Articles & Two and Three of the Treaty) which included Māori \\
& authority and autonomy (tino rangatiratanga). \\
The Treaty envisaged a new country wherein two \\
peoples (Māori and Pākehā) would live together with \\
their own laws and customs. The interface between \\
Te Ao Pākehā and Te Ao Māori was to be governed \\
on the basis of mutual respect and partnership. \\
Inherent in the Treaty relationship was that Māori, \\
whose laws and autonomy were guaranteed and \\
protected, would "have the right to continue to \\
govern themselves along customary lines, or to \\
engage with the developing settler and modern \\
society, or a combination of both" (Waitangi Tribunal \\
2018, p. 189). Māori were meant to be able to choose \\
to continue to live according to their tikanga (laws) \\
and ways of life (within Te Ao Māori), to engage with \\
Te Ao Pākehā society and economy, or to combine \\
aspects of both worlds and walk in both. Their \\
choices were meant to be free and unrestricted. \\
Options
\end{tabular}




\begin{tabular}{ll}
\hline Treaty Principle & Interpretation of the principle \\
\hline $\begin{array}{l}\text { Equity and equal } \\
\text { treatment }\end{array}$ & $\begin{array}{l}\text { The principles of reciprocity, autonomy, active } \\
\text { protection, and partnership required the Crown to } \\
\text { act fairly in its treatment of Māori (and Pākehā). The } \\
\text { Crown cannot use its powers of governance to } \\
\text { provide unfair advantages to Pākehā at the expense } \\
\text { of Māori interests. Likewise, the Crown must not } \\
\text { provide equal treatment to Māori groups nor foster } \\
\text { divisions between them. } \\
\text { In situations where the Crown acted in excess of its } \\
\text { powers of kāwanatanga and/or breached the Treaty } \\
\text { terms, and Māori suffered prejudice as a } \\
\text { consequence, then the Crown possesses a clear duty } \\
\text { to set matters right. The Crown must provide redress } \\
\text { in the form of a remedy to compensate Māori and to } \\
\text { resolve the grievance. }\end{array}$ \\
\hline
\end{tabular}

The Tribunal's findings, however, are not laws, and therefore it is left up to the Crown and Māori groups to directly negotiate as a means to seek to address Māori claims about Treaty breaches and injustices committed as a consequence which is a process undertaken by a separate institution. In 1994, the Office of Treaty Settlements (OTS) was established (located within the Ministry of Justice and entirely distinct from the Waitangi Tribunal) to negotiate with individual iwi (and sometimes larger pan-iwi groupings) about legal-financial reparation packages that acknowledge and sought to address the Crown's failures to honour the Treaty and as a means to reconcile with Māori (discussed further in Chap. 7) (Jones 2016, pp. 21-22).

As a consequence of the negotiations between OTS and iwi, a range of 'Treaty settlements' started to emerge (from the mid-1990s with the Waikato-Tainui Raupatu Settlement and continuing into the 2020s). These Treaty settlements include a formal apology from the Crown for historic and contemporary injustices against a particular iwi, financial reparations to the iwi (monetary payments and return of Crown landholdings), and the introduction of new legislation (Jones 2016; Williams et al. 2018). The Treaty settlement statutes provide an additional legislative means by which Māori are seeking to protect and maintain their connections with their awa and whenua, which in many instances extends 
those provided under the RMA. Many statutes explicitly acknowledge the significance of lakes and rivers to specific iwi as well as incorporate elements of tikanga Māori. The Deed of Settlement that contributed to the Ngāi Tahu Claims Settlement Act (1998) includes aspects to tikanga. Embedded in the statute are purākau (traditions and stories) of the whenua, such as the origin story of Aoraki/Mount Cook and the naming of the South Island, which Ruru argues provides a catalyst for transforming legal education and public understandings of law. Likewise, the Ngāi Tahu Settlement Act includes statutory recognition of Ngāi Tahu social, cultural, spiritual, political and economic connections with the Mata-Au (Clutha) River. The Act records that the river is in possession of its own life force (mauri) and is a descendant of the atua (gods) of Māori. More recent Treaty settlements, including those with Waikato-Tainui and Ngāti Maniapoto, include specific provisions for Māori iwi to co-govern and co-manage culturally significant sites, including rivers, lakes and national parks. And, most notably, the recognition of the legal personhood of Indigenous ancestors (the forest of Te Urewera and the river of Whanganui) (New Zealand Parliament 2014, 2017).

Indeed, the emerging backbone of legal pluralism in Aotearoa is tied to recognition of the Māori interests under Treaty settlements. A range of new institutions were instituted from the mid-2000s to co-govern and co-manage a range of natural resources and geo-regions as a way of addressing injustices as well as meeting the Crown's obligations under the Treaty. These include a plethora of formal agreements that now position Māori as partners within formal decision-making processes relating to freshwater systems, which represents a radical departure from past practices of governing and managing rivers in Aotearoa (as demonstrated previously in Chaps. 4, 5, and 6). Although each agreement differs in its contents, including the institutional structures and functions it establishes, a common thread amongst all of these agreements is that Te Ao Māori is positioned at the heart rather than being excluded or marginalised. Emphasis within the new agreements is placed on mātauranga Māori (Māori knowledge) and tikanga (customary laws and correct protocols), which includes the inclusion of the specific values of different iwi, their knowledge, histories, and aspirations for the future within river co-governance and co-management. We will now turn our attention to 
recent Treaty settlements and how these settlements (accompanied by resulting legislation) are exemplars of both legal pluralism and ontological pluralism.

\section{Treaty Settlement: Ngā wai o Maniapoto (Waipā River) Act and the Waiwaia Accord}

In September 2010, a Deed of Settlement between the Crown and Ngāti Maniapoto (by the mandated negotiation party Maniapoto Māori Trust Board) was signed and (as with other Treaty settlements) contained the historical account and reasons for the claim, acknowledgements, and apology from the Crown (Jones 2016). The deed also extended the cogovernance and co-management arrangements that operated in respect of the Waikato River and Lower Waipā River (established under the Crown's other deeds of settlement with neighbouring iwi Waikato-Tainui, and Ngāti Tuwharetoa, Raukawa and Te Arawa) to include Ngāti Maniapoto and the Upper Waipā River (discussed in further depth in Chap. 7). At the same time as the deed was signed, Ngāti Maniapoto and the Crown also signed the Waiwaia Accord, which further affirmed both parties' commitment to partnership through the co-governance and comanagement of the Waipā River. Later legislation, introduced in 2012, established the institutional arrangements for co-governance and comanagement (through the Waikato River Authority, which is discussed in further detail in Chap. 7).

The Deed of Settlement and Waiwaia Accord both incorporate tikanga Māori and demonstrate Maniapoto ways of thinking wherein their whakapapa (genealogical connections) is interwoven with the ebb and flow of wai (water) within their awa, its mauri (life force) and mana (power and authority). The Waiwaia Accord includes sections in Te Reo Māori (the Māori Language) that highlights this understanding:

Ko te mauri, ko te waiora o te Waipa ko Waiwaia

Ko Waipa te toto o te tangata! Ko Waipa te toto o te whenua,

koia hoki he wai Manawa whenua!

Ko Waipa tetehi o nga taonga o Maniapoto whanui. 
Ancestral authority handed down from generation to generation in respect of Waiwaia,

Guardian of the Waipa River. (Ngāti Maniapoto et al. 2010)

Waiwaia is a taniwha (supernatural creature) and kaitiaki (guardian) of the Waipā River and the Ngāti Maniapoto people, and is identified as the essence and wellbeing of the Waipā River, and the personification of the waters of the Waipā River. The phrase 'mana tuku iho o Waiwaia', which is included in the Deed of Settlement and Waiwaia Accord, means the ancestral authority and prestige handed down from generation to generation in respect of Waiwaia. In the Deed of Settlement, Waiwaia Accord, and subsequent legislation (introduced to parliament in 2012) the status of Te Awa o Waipā as a taonga (treasure) to Maniapoto and tūpuna (ancestor) is recognised by the Crown; similarly, recognition is given to Maniapoto obligations as kaitiaki to restore, maintain and protect the mana, mauri, and wairua of all the waters within the rohe of Manaipoto (Ngā Wai o Maniapoto). In doing so, the ontological and epistemological underpinnings of Ngāti Maniapoto (their values, worldviews, and tikanga) are explicitly acknowledged and incorporated within the legal agreements, which includes the Ngā Wai o Maniapoto (Waipā River) Act 2012. Part of the legislation is quoted below as it highlights the ways in which (for the first time) the Crown formally recognised the values, and tikanga of Ngāti Maniapoto with respect to the Waipā River:

(10) To Maniapoto, the Waipā River is a single indivisible entity that flows from Pekepeke to its confluence with the Waikato River and includes its waters, banks, bed (and all minerals under it) and its streams, waterways, tributaries, lakes, fisheries, vegetation, floodplains, wetlands, islands, springs, geothermal springs, water column, airspace and substratum as well as its metaphysical elements with its own mauri. (New Zealand Parliament 2012)

Ngāti Maniapoto ontological underpinnings are demonstrated in the above words, articulating the concepts of reciprocity, caring, and belonging. Both Ngāti Maniapoto and Te Awa Waipā need each other, they are indivisible, a relationship without a start or an end, within which those 
Māori who are mana whenua possess responsibilities as kaitiaki (guardians) to work to ensure the health and wellbeing of all (human and nonhumans alike). Human and more-than-human actors are in close and ongoing relationships with one another; birds, mountains, trees, fish, rivers, and taniwha all possess the same genealogical lines of descent as human beings. Iwi members articulate how damage to their ancestral river diminishes the mauri of the river and causes them (as mana whenua) and their more-than-human kin harm. As one Ngāti Maniapoto member states: $[\mathrm{Ko}]$ te wai te toto o te whenua, water is the blood of the land. The land is the mauri of the people, keeps the people alive. If the water goes bad, the land goes ...bad, the people die" (Iwi Rep 6 2020). Accordingly, environmental injustices occur not only because of material manifestations of environmental degradation (distributive injustice) and the marginalisation of Māori from decision-making processes (procedural injustice), but also because of the misrecognition of mātauranga and tikanga which is premised on the non-divisible reciprocal relationships between humans and more-than-humans.

For Ngāti Maniapoto, the Waipā River Act goes some way to redress injustice by misrecognition by including Ngāti Maniapoto values and principles. The legislation includes sections in Te Reo Māori (the Māori language) as well as including reference to the taniwha. It also establishes co-governance and co-management arrangements between iwi and the Crown over the Upper Waipā River; however, the design and implementation of co-governance agreements are now being critiqued by iwi for disregarding Māori legal and political governance systems and providing inadequate means to achieve iwi environmental justice (as we outlined in Chap. 7). Yet, the legislation does show evidence of legal pluralism and is a significant marker of the shift in relationships between Ngāti Maniapoto and the Crown and the potential to expand the narrow confines of the settler-colonial legal order to include tikanga. It also hints at the possibilities of recognition and acts to empower the coexistence and flourishing of many worlds (Dunford 2020). The inclusion of Indigenous ontologies, as we later demonstrate in Chaps. 8 and 9, is a critical way of destabilising conventional scientific and technocratic approaches to river management, and provides new ways to address complex social-environmental issues within freshwater systems in a relational, and holistic manner 
(Crow et al. 2018; Parsons et al. 2019). In the case of the Waipā River, achieving the overarching purpose of the Waipā River Act requires tolerance for ontological inconsistency rather than treating Māori and modernist ontologies as mutually exclusive and in opposition (Salmond et al. 2014).

\section{Treaty Settlement: Te Awa Tupua (Whanganui River)}

Another Treaty settlement, and resulting co-governance arrangement, is that of the Whanganui River is recognised as a legal personality. As part of their negogiations with the Crown to reach Treaty settlement the various iwi who whakapapa to the Whanganui River, requested that the river be officially given the status as a legal person. The 2014 Treaty settlement (Ruruka Whakatupa Te Mana o te Iwi o Whanganui) recognised iwi and hapū deep-seated and ongoing relationships to their river, provided an apology to iwi and hapū for Treaty breaches, as well as a financial settlement ( $\$ 80$ million NZD). Iwi requested that the river be given legal personhood as a means to reconcile Te Ao Māori conceptualisation of rivers as more-than-human actors with Te Ao Pākehā and Western legal traditions. It was also a deliebrate attempt to find a way to protect and restore the mauri of their awa, which (like the Waipā River) had become severely degraded as a consequence of settler-led land-use changes, governance regimes, and management systems focused on agricultural productivism at the expense of freshwater ecosystem functioning (Charpleix 2018; Forster 2016; Morris and Ruru 2010; Ruru 2012; Salmond 2017).

The common whakatāuki (proverb) "Ko au te awa, to te awa ko au" (I am the river and the river is me) summarises the relationships between Whanganui iwi and their river, as well as Whanganui iwi role as kaitiaki (Brierley et al. 2019; Bryan 2017; Wilson 2019; Youatt 2017). The Whanganui River approach is a legal hybrid that incorporates components of Māori tikanga (customary law) that perceive rivers to be ancestors and/or kin (connected through genealogical connections to specific hapū and iwi) and settler legal traditions in Aotearoa which incorporates 
the Treaty principle of partnership (Forster 2016; Ruru 2013; Winter 2018). It is a new legal framework that attempts to, Forster maintains, "secure the autonomy of both Māori and the Crown [the New Zealand Government] in relation to governance and management of natural resources associated with the river" (Forster 2016, p. 325).

In an approach that resonates with the framing of the Waipā River as a tūpuna (ancestor) and kin of Ngāti Manaipoto (under Waipā River Act), the Whanganui River, within Te Awa Tupuna legislation, conceptualises the Whanganui River as a more-than-human actor who has and still is suffering ongoing damage as a consequence of human activities. The 2017 Te Awa Tupua (Whanganui River Claims Settlement Act) declares that the Whanganui River is "an indivisible and living whole" and encompasses the river from its headwaters in the mountains to the Tasman Sea and incorporates all material and spiritual dimensions and is afforded legal personhood with all the powers, obligations, and rights as a person. The status of a legal person means that the river can (in theory) enforce its rights over other legal persons. There is the potential that legal cases could be launched where the river is a plaintiff (such as those taken in Ecuador on behalf of Nature or Pacha Mama in which the courts ruled in favour of upholding the rights of Nature and required government to take action to restore a degraded river) (Clark et al. 2018).

In addition to being made a legal person, the 2017 act also gave the river an independent voice within decision-making. Te Awa Tupua is to be represented by a two-person committee (Te Kōpuka nā Te Awa Tupua) made up of one person who represents local iwi and the other a person nominated by the Crown. The committee is meant to act as "the human face of Te Awa Tupua". These human actors then must speak on behalf of the voiceless Te Awa Tupua (Charpleix 2018; New Zealand Parliament 2017). Under Te Pou Tupua rests, (in descending order of influence and authority), an advisory group (Te Karewao) as well as a strategy group (Te Kōpuka) both of which are made up of iwi and Crown representatives. In addition, broader community representation is given space in a collaborative community group (Te Heke Ngahuru) those membership structure and overarching purpose is looser and includes any person with interests in the river. The institutional arrangements for the Whanganui River (designed to "support the health and well-being of Te Awa Tupua" 
the legal person and the right) include the committees listed earlier, which presents a new approach to co-governance and co-management in Aotearoa (which is funded through a separate grant, with an initial funding of $\$ 30$ million NZD provided by the Crown) (Clark et al. 2018).

The frameworks for governing and managing Te Awa Tupua recognise, afford value to, and provide funding for Māori co-governance and comanagement, and in doing so recognise and open up ontological and epistemological spaces within the settler-state for Māori ways of knowing, being, and interacting with more-than-human entities. The principles of legal personhood as well as co-governance and co-management arrangements all reinforce the indivisibility of Whanganui iwi and the river, including their rangatiratanga and wairua, and the interconnectedness of their sovereignty with that of the river. In 2020, Te Awa Tupua has yet to be a plaintiff in a legal case, and it remains to be seen how the legal personhood of Te Awa Tupua will play out within Aotearoa's courts (and if the decisions will parallel or challenge those made in Ecuador in regard to Pacha Mama) (Clark et al. 2018; Muller et al. 2019).

Three years earlier, in 2014, Te Urewera (mountain range covered by forest in the North Island) also received legal personhood through legislation as part of the Treaty settlement between Ngāi Tühoe and the Crown (New Zealand Parliament 2014). The legislation means that no one owns Te Urewera (which was unlawfully taken from Ngāi Tūhoe and converted into a national park by the Crown) and it effectively own's itself. Te Urewera is similarly represented by a committee comprised of iwi and government agency representatives. While some legal scholars argue that Te Urewera did not receive legal personhood as a method to ensure environmental protection (as there were already laws in place to prevent or mitigate environmental degradation as it was a national park), we note that generations of Ngāi Tühoe protested about the negative consequences of settler-colonial rule on their rohe; which included both material and metaphysical losses and damages linked to Crown actions to suppress the sovereignty and authority of Ngāi Tūhoe (Morris and Ruru 2010; New Zealand Parliament 2014; Ruru 2018b; Waitangi Tribunal 1999, 2009). For Ngāi Tūhoe, like other Indigenous peoples, decisionmaking authority is inextricably tied to their environmental justice. 
With the enactment of such new legislation, the legal framework of Aotearoa is being stretched and incrementally or more radically reconfigured from singular to plural in viewpoint. Scholars Christine Winter (2018) and Anne Salmond (2019) argue that while this singular (Te Ao Pākehā) to plural (Te Ao Māori and Te Ao Pākehā) expansion is being deployed through the existing colonial legal order, it is still facilitating a far greater recognition of Māori knowledge and tikanga than previous legislation allowed for. Indeed, the acknowledgement of mātauranga and tikanga surrounding rivers (and other more-than-human actors) possessing both mauri and mana within legal agreements, legislation and cogovernance arrangements is a significant shift from previous statutes (such as the original RMA introduced in 1991) that contained mentions to Māori cultural values and wāhi tapu (sacred sites). Such legal pluralism, Ruru (2017) and Hickford (2018) suggest, is an important and necessary step to decolonise environmental governance in Aotearoa by explicitly acknowledging Māori worldviews, cultural identities and continuance, mātauranga and tikanga. A key part of this involves recognising that, from a Te Ao Māori perspective, landscapes and waterscapes are inhabited by living generations of people as well as their ancestors (human and more-than-human kin). The duties and obligations to show reciprocity, hospitality, and care for one's kin extended are therefore intergenerational and are based on the need to ensure relationships between all beings (human and more-than-human) are balanced and mutually beneficial. These deeds of settlements, legislation and co-governance arrangements, which recognise (to some degree) the interests, agency, and rights of the more-than-human realm disrupt the anthropocentricism inherent in Western liberal conceptualisations of EJ. Relationships based on whakapapa that extend across generations highlights the ways in which justice is always (from Te Ao Māori perspective) encompass both the needs and responsibilities of humans and more-than-human with "generations to come [holding] as much interest in the land" and waters "as the individuals living at any point in time" (Stephenson 2001, p. 166).

All these statutes passed through New Zealand Parliament accompanied by a formal apology from the Crown (the New Zealand Government) for the long-term damage that rivers (and its Māori kin groups) suffered as a consequence of settler-colonialism (specifically government actions 
and inactions that breached the Treaty). In all instances, the resulting cogovernance arrangements ensure that Māori roles as kaitiaki are formally recognised and incorporated into the co-governing models for these geofeatures; Mãori comprise one of the two representatives that were appointed to represent Te Awa Tupua, similarly they make up fifty per cent of Te Urewera Board (for first term and thereafter making up twothirds), and fifty per cent of the Waikato River Authority (Collins and Esterling 2019; New Zealand Parliament 2014; Rangitāiki River Forum 2015; Waikato River Authority 2016).

Through these legal mechanisms, the reciprocal and ongoing connections between rivers, forests, lands and their Māori kin groups (whanau/ family, hapū/sub-tribe, iwi/tribe) are recognised. These relationships are "an indivisible and living whole from the mountains to the sea and incorporating all its physical and metaphysical elements" (Ruru 2018b).

A pivotal part of the decolonising processes is the disruption and destabilisation of the privileging of Western ontologies and epistemologies and allowing space for different ways of thinking and being. Muller et al. (2019) argues that the Whanganui and Te Urewera examples demonstrate a profound shift in power to Māori iwi by enabling Māori worldviews to be given status in environmental governance and management decisions whilst still being situated within the legal frameworks of the settler-state. Muller et al. (2019) interprets the agreements as evidence of 'nation-building' approaches to environmental governance and management wherein the settler-state of Aotearoa recognises Māori sovereignty (which was first acknowledged under Te Tiriti o Waitangi in 1840 but ignored until 1975). They argue that the new legal agreements are testaments to the importance of the value of "ontological pluralism through the assertation of Indigenous sovereignties" (Muller et al. 2019, p. 9). Indeed, as Whyte, Wildcat and other Indigenous scholars argue, achieving environmental justice for Indigenous peoples requires "the recognition and restoration of reciprocal relationships between people and places" which includes recognition of more-than-human beings and multiple worlds (Wildcat 2013, p. 514). 


\section{Complexities of Enacting Legal Pluralism}

It is critical to note that the different wording in Treaty settlements, once agreed on by iwi and the Crown and formularised within legislation, does not ensure consistency in understanding or application. The complexities of co-existence (between Indigenous and non-Indigenous worlds, worldviews, and legal orders) remains (despite Treaty settlements) and invariably result in legacies of assorted legal rights, interests and uses arising from setter-colonialism. Thus, while the Whanganui River is defined under the Te Tupua Awa statue as a legal person that is an indivisible entity (waters, subsoil, riverbed, plants, airspace above its waters), other legislation still compartmentalises the river. As legal scholar Hickford notes, the coastal marine area (from the Whanganui River to the Cobham Street Bridge within the township of Whanganui) is subject to the Marine and Coastal Area (Takutai Moana) Act 2011, which states that neither the Crown nor any persons can own the common coastal and marine area (Hickford 2018, p. 168). Accordingly, Whanganui iwi aspirations for invisibility, which are embedded within their Deed of Settlement and the Tupua Awa Act, are still forced to contend with several statutory regimes (products of Western ontologies and epistemologies) that continue to compartmentalise river systems.

The realities of translating legislation (this came about from Treaty settlements) into meaningful actions that address environmental injustices against Māori and their more-than-human relatives remains a politically fraught and power-laden process. Hickford refers to the potential for "interpretive risk" which results when:

strangers to the processes of [Treaty settlement] negotiations end up interpreting what was agreed at earlier moments in time and constructing different ways of understanding those concepts captured in the legislation and deeds of settlement. Possibilities of mutual incomprehension persist ... [in this] 'middle ground'. (Hickford 2018, p. 171)

While parties may be able to work together towards common goals, this did not mean that there is shared understandings of concepts and practices. However, since the Crown defines parameters of Treaty 
settlement processes (including negotiations, awarding of financial compensation packages and passing legislation) it is fair to say that the Crown is in a stronger bargaining position when it comes to later determinations of the meaning of concepts. Indeed, despite the progress made toward greater legal and ontological pluralism within Aotearoa, the settler-state continues to dictate the terms by which iwi can participate in environmental governance and management decision-making processes. Accordingly, it is the settler-state who determines how Māori tikanga, knowledge, and relationships with their rohe are defined and recognised (through legislation and governance arrangements), which may leave iwi open to further injustices (Whyte 2011, pp. 199-200).

Indigenous Canadian scholar Zoe Todd warns of the dangers of Indigneous knowledges and ideas being appropriated in Euro-Western contexts "without Indigenous interlocutors present to hold the use of Indigenous stories and laws to account flattens, distorts, and erases the embodied, legal-governance and spiritual aspects of Indigneous thinking" (Todd 2016, p. 9). Todd's warning was made in the context of nonIndigenous scholars employing Indigenous knowledges through Eurocentric theories and methods; such a critique was made earlier by Māori scholar Linda Smith in her seminal work Decolonising Methodologies first published in 1999 (Smith 2013; Todd 2016; Watts 2013). Yet in the context of the interpretation of deeds of settlement, legislation, and policies, we extend Todd's warning to include non-Indigenous decisionmakers interpeting and employing mātauranga, tikanga and Māori principles (such as mauri and kaitiakitanga) without consideration of the embodied expressions of Indigenous laws, stories, songs, and practices as inter-threaded together in "Indigenous-Place Thought" and Indigenous self-determination (Todd 2016, p. 9). There is an "interpretive risk" (whereby strangers to the reconcilitation process interprete the meanings of terms, settlements, and statutes differently from those people who originally agreed to them) as a consequence of three key factors. First, high staff turnover (including replacement of elected officials) mean that few government officials remain in positions long enough to be involved in both the creation and implementation of agreements (Treaty settlements, legislation, co-governance arrangements). New elected officials and government employees are often unfamilar with local specifics 
(socio-political, cultural and historical contexts) in which the agreements between iwi and the settler-state were formed as well as the intended meaning of key terms and mechanisms within deeds of settlement and statutes. The second (inter-related) factor (associated with interpretive risk) is the potential that non-Māori decision-makers (who still make up the majority of the New Zealand Parliament, central government departments and local government bodies) misunderstand Māori concepts and ways of thinking and in doing so misrecognise Māori interests. Indeed, there is a threat that tikanga, mātauranga, and iwi requirements that are vital for Indigenous Environmental Justice (IEJ) are not acknowledged at all. As we note earlier in Chap. 5, lack of recognition can occur when decision-making powers rests in the hands on one culture who by design or accident marginalise other cultures' knowledge, laws, worldviews and modes of living. Within Aoteraoa the power to interpret and decide what a legislation means and how it should be applied still largely rests in the hands of non-Māori individuals (government officials and members of judicary) situtated in the Te Ao Pākehā. Accordingly, there are multiple interpretative risks associated with the new agreements tied to the complete failure to or partial acknowledgement of Indigenous ontologies and epistemologies; the problematics of recognition and interpretation extend to include Indigenous legal orders, governance structures, as well as Indigenous demands for greater economic and political autonomy (Ahmad 2019; Grosfoguel 2015; Maldonado-Torres 2016).

Within the context of academia, Watts and Todd suggest that the nonIndigenous scholars' current interest in studying Indigenous ways of thinking (the so-called ontological turn) and representing more-thanhuman ontologies as the solution to the global planetary crises of the Anthropocene, more often than not takes place without any recognition given to Indigenous peoples' lived realities (of socio-economic deprivation, multiple forms of violence, political marginalisation, lack of access to basic services, and environmental degradation of their ancestral lands and waters) (Bécares et al. 2013; Harris et al. 2006; Leonard et al. 2020; Mascarenhas 2007; Tobias and Richmond 2014; Todd 2014; Watts 2013). Likewise, attempts by the settler-state to recognise those elements of Māori knowledge and tikanga that are easily consumable (less discomforting) for the dominant political and social group (Pākehā) holds the 
potential to rearticulate existing injustices and is yet another example of what American anthropologist Deborah Bird Rose calls "deep colonising" (Rose 2004). Our notes of caution, however, are not a critique of current efforts to expand Aotearoa's legislation and governance frameworks to embrace Indigenous ways of thinking and being, but rather that greater attention needs to be devoted to how pluralism can operate in situations where inequitable power relations between Indigenous and non-Indigenous peoples remain. Indeed, all of those parties (scholars, politicians, government officials, Indigenous leaders) involved in advocating for, creating, and implementing these legally and ontologically pluralistic agreements, aimed at reconciliation and addressing Indigenous injustices, need to continue to be attune to the multiple manifestations of colonialism.

Although many Māori describe themselves as ambicultural (who walk in the worlds of Māori and Pākehā), the legal and political structures of Aotearoa are still not ambicultural (Winter 2018, p. 207). It is critical that we recognise that despite the passage of new legislation:

The colonial moment has not passed. The conditions that fostered it have not suddenly disappeared. ... The reality is that we are just an invasion or economic policy away from re-colonising at any moment. (Todd 2016, p. 16)

Therefore, it is important to think about how the turn towards ontological pluralism within legislation, policies and governance structures may reinforce inequitable power arrangements (Todd 2016, p. 9). Māori legal scholar Ani Mikaere warns that Māori should not:

settle for mere improvements in the Pākehā system as being the ultimate goal. It is all very well to be making Pākehā law and legal institutions as Māori friendly as possible, but only so long as we do not become comfortable that we forget to aim for some more ... to remind ourselves constantly about what it is that tino rangatiratanga ultimately demands. (Mikaere 2005 , p. 24) 
The Treaty settlements and emergent co-governance arrangements, Mikaere and Te Aho warn, are serving to enhance the single (settlercolonial) legal order to better acknowledge tikanga "for the sake of national cohesion" rather than actually creating a "plural legal order" (Aho 2018, p. 156). Indeed, the consequences of making slight improvements to the settler-colonial legal system means that iwi interets in and responsibilities to their rohe are continuing to being undermined, with importance still given to the values and interests of the settler-state and settler society as a whole (Aho 2018; Mikaere 2011). The declaration of the Whanganui River as a legal person that owns itself and no one can assert propriety rights over it is a political compromise between Māori and Pākehā interests (Salmond 2017; Salmond et al. 2019).

Legal personhood effectively neutralised the highly politicised issue of Māori ownership of water, and meant that the river cannot be divided into units to be commodified, traded, and sold (Strang 2014). In 1990, when the Waitangi Tribunal released its inquiry report into the Whanganui River claim, the Tribunal concluded that Whanganui iwi possessed what amounted to proprietorship of the river. Iwi legally asserted their interests in their awa even though, in the words of the Tribunal, "Māori did not think in terms of ownership in the same way as Europeans. What they possessed is equated with ownership for the purposes of English or New Zealand law" (Waitangi Tribunal 1999). Heated public debates followed the release of the report, with Pākehā expressing fear that Māori ownership would restrict their entitlements to water. In response to the Crown issued statements to remind the public (and iwi) that under Aotearoa's common law no one can own water (rivers, lakes, seas) and that the Tribunal is not a court and did not determine issues of law (Aho 2018; Hickford 2018; Te Aho 2019). A similar situation occurred with regard to Te Urewara. The failed attempts of iwi to gain proprietorship preceded the use of legal personality for both $\mathrm{Te}$ Urewara and the Whanganui River. The use of legal personhood, legal scholar Mark Hickford argues, is a mechanism "to ameliorate any perceived anxieties as to a non-Crown actor excluding through proprietorship any third parties who might have enjoyed relatively unfettered access" (Hickford 2018, p. 168). Legal personhood is presented as something less discomforting for the dominant social group (Pākehā), 
which preserves public access, and ensures that the geo-entity cannot be owned by any human being or institution (but more specific by Māori). Indeed, the whole concept of legal personhood is a Western concept, Indigenous scholar Jones observes, which is not the same as Māori ontologies regarding more-than-human beings possessing their own mauri, wairua, and mana (Jones 2016, p. 98). Indeed, scholars caution such attempts to codify Indigenous concepts within Western legal orders due to the possibilities of misrecognition and the associated injustices (Coulthard 2014; Hickford 2018, pp. 168-169). Indeed, in the next chapter we highlight the limits of recognitional-based environmental justice approaches in the context of the co-governance of the Waipā River.

At an international scale, Karen Engle (writing in the context of the United Nations Declaration of the Rights of Indigneous Peoples) suggests that Indigenous leaders are compromising too much in strategies that emphasise the cultural and spiritual elements of their claims and downplay claims to stronger forms of self-determination. The impact is to "reify identity and indigneous rights and displace many of the economic and political issues that initally motivated much indigenous advocacy: issues of economic dependency, structural discrimination, and lack of indigenous autonomy" (Engle 2011, p. 145). Morris and Ruru state that "just because Maori have a personified worldview, it is incorrect to assume that they will always favour non-development. Maori do not tend to ascribe to a preservation standpoint, but rather a sustainable one" (Morris and Ruru 2010, p. 49). Similarly, Māori leaders (switching between Te Ao Pākehā notions of ownership and resources and Te Ao Māori concepts of rangatiratanga and kaitiakitanga) to emphasise that their interests in freshwater; their responsibilities as kaitiaki involves a delicate balance between their capacities to maintain and enhance the hauora (health) of their awa, while also seeking economic development opportunities for iwi/hapu/whānau (Bargh 2018; Bargh and Van Wagner 2019; Jones 2016; Muru-Lanning 2012, 2016a, b). Indeed, iwi leaders argue for the Treaty to be honoured and their rangatiratanga respected, which includes their entitlements to access and use their awa for economic purposes (alongside social, cultural, and spiritual; indeed, within Te Ao Māori there is no division between domains as everything is 
connected, the health and flourishing of the land, water, plants, animals, spirits, and people are always interwoven) (Durie 2006; Johnston 2018; Jones 2016; Walker 1996; Walker and McIntosh 2017). Indeed, the tension remains with Aotearoa, as Māori EJ continues to be constrained by the following stipulations: firstly, Māori knowledge, tikanga, and interests in awa continues to only exist within the prescribed boundaries set by the settler-state; and secondly, in instances where Māori values, laws, and entitlement conflict with those of Te Ao Pākehā, the settler-colonial values take precedent.

In other settler societies, different forms of recognition of Indigenous interests in and rights to water are occurring through colonial legal systems. In the United States, decisions by the Supreme Court of Hawai' i are increasingly recognising Indigenous Hawai'ians (Kanaka Känaka 'ōiwi or Kānaka Maoli) connections to their rivers and streams but in different ways. In the United States, a longstanding legal precedent states that all citizens possess the right to enjoy and take care of things that are common to all (under law of nature) and are recognised as "public trust doctrine" (Blumm 1988; Ede 2002; Salmond 2018). In 2000, in a legal case between Indigenous Hawai'ians and local farmers, who campaigned to restore the water to streams that had been diverted by sugar plantations, the Supreme Court of Hawai'i ruled that public trust doctrine applies to all water resources and argued that this necessitated the need to adequately protect customary Indigenous Hawai' ian rights alongside the preservation of biodiversity, scenic landscapes, and waters for all citizens. A later legal ruling by the court, in 2012, for the Four Great Waters case, expanded the public trust doctrine further, and overturned water permits awarded to two companies on the basis that the permits allowed water extraction that impacted on customary Indigenous Hawai'ian practices and the rights of ordinary citizens "public trust" interests in freshwater use (Ede 2002; Kyle 2013; Papacostas 2014). Public trust doctrines are similarly used in other countries, including India and Ecuador (where nature itself is recognised in the constitution). In India, the Supreme Court determined that public trust doctrine "imposed on us by the natural world must inform all of our social institutions" and Indian society must demonstrate "respect for plants, trees, earth, sky, air and water and every form of life” (O’Donnell 2018; O’Donnell and Talbot-Jones 2018). 
In the context of Aotearoa, anthropologist Anne Salmond argues that while legislation such as Te Awa Tupua Act (Whanganui River) goes someway in recognising Māori understandings of kinship centred on whakapapa, it could be taken further still. "In the spirit of bringing "two laws" together", Salmon suggests, an Aotearoa version:

of a public trust doctrine might recognise both the common-law entitlement of all citizens to the 'lawful enjoyment' of waterways and whakapapa relationships between particular Māori kin networks and ancestral springs and rivers. (Salmond 2018, pp. 189-191)

\section{Conclusion}

The emergence of hybrid institutional arrangements and changing jurisprudence, in Aotearoa, demonstrate that there are a range of different avenues being employed by which Māori mana, mātauranga and tikanga can be fostered within the context of freshwater governance and management. Other examples from around the world also attest to the opportunities to address the ongoing ontological dissonance within colonial laws and governance structures, particularly in the context of freshwater governance and management. Different legal and governance arrangements, from legal personhood, to the rights of Mother Nature, and public doctrine, highlight the multiple epistemological entry points and avenues that can be taken through which legal pluralism can be enacted as a means to enable Indigenous peoples' to achieve environmental justice (Clark et al. 2018; Curley 2019; Kyle 2013; Morris and Ruru 2010; Papacostas 2014; Wilson 2020; Yates et al. 2017). Yet, while new statues, court judgements, and agreements to co-govern geo-entities (between Indigenous and settler-states) all indicate efforts to disrupt settler-colonial knowledge and political structures (as part of the decolonising process), we also note the complexities and challenges of attempting to accommodate and reconcile multiple legal systems in the context of ongoing inequitable power relations between Indigenous peoples and settler-nations. 


\section{References}

Ahmad, N. B. (2019). Mask Off - The Coloniality of Environmental Justice. Widener Law Review, 25, 195.

Aho, L. T. (2018). Governance of Water Based on Responsible Use - An Elegant Solution? In B. Martin, L. T. Aho, \& M. Humphries-Kil (Eds.), ResponsAbility: Law and Governance for Living Well with the Earth (pp. 143-164). London: Routledge.

Anderson, A., Binney, J., \& Harris, A. (2015). Tangata Whenua: A History. Wellington: Bridget Williams Books.

Bakker, K., Simms, R., Joe, N., \& Harris, L. (2018). Indigenous Peoples and Water Governance in Canada: Regulatory Injustice and Prospects for Reform. Water Justice, 193-209.

Bambridge, T. (2016). The Rahui: Legal Pluralism in Polynesian Traditional Management of Resources and Territories. Canberra: Anu Press.

Bargh, M. (2018). Māori Political and Economic Recognition in a Diverse Economy. In D. Howard-Wagner, M. Bargh, \& I. Altamirano-Jimenez (Eds.), The Neoliberal State, Recognition and Indigenous Rights (pp. 293-307). Canberra: ANU Press.

Bargh, M. (2020). Challenges on the Path to Treaty-Based Local Government Relationships. Kōtuitui: New Zealand Journal of Social Sciences Online, 1-16. https://doi.org/10.1080/1177083X.2020.1754246.

Bargh, M., \& Van Wagner, E. (2019). Participation as Exclusion: Māori Engagement with the Crown Minerals Act 1991 Block Offer Process. Journal of Human Rights and the Environment, 10(1), 118-139.

Bark, R. H., Barber, M., Jackson, S., Maclean, K., Pollino, C., \& Moggridge, B. (2015). Operationalising the Ecosystem Services Approach in Water Planning: A Case Study of Indigenous Cultural Values from the MurrayDarling Basin, Australia. International Journal of Biodiversity Science, Ecosystem Services \& Management, 11(3), 239-249.

Baum, A. (2019). Mni Wiconi (Water Is Life): Knowledge, Power and Resistance at Standing Rock. Ideas from IDS: Graduate Papers from 2017/18, 9.

Bécares, L., Cormack, D., \& Harris, R. (2013). Ethnic Density and Area Deprivation: Neighbourhood Effects on Māori Health and Racial Discrimination in Aotearoa/New Zealand. Social Science \& Medicine, $88,76-82$.

Belich, J. (1996). Making Peoples: A History of the New Zealanders, from Polynesian Settlement to the End of the Nineteenth Century. Auckland: Penguin Press. 
Belich, J. (2013). The New Zealand Wars and the Victorian Interpretation of Racial Conflict. Auckland: Auckland University Press.

Bell, A. (2018). A Flawed Treaty Partner: The New Zealand State, Local Government and the Politics of Recognition. In D. Howard-Wagner, M. Bargh, \& I. Altamirano-Jimenez (Eds.), The Neoliberal State, Recognition and Indigenous Rights: New Paternalism to New Imaginings (pp. 77-92). Canberra: ANU Press.

Bergman, I. (2006). Indigenous Time, Colonial History: Sami Conceptions of Time and Ancestry and the Role of Relics in Cultural Reproduction. Norwegian Archaeological Review, 39(2), 151-161.

Berry, K. A., Jackson, S., Saito, L., \& Forline, L. (2018). Reconceptualising Water Quality Governance to Incorporate Knowledge and Values: Case Studies from Australian and Brazilian Indigenous Communities. Water Alternatives, 11(1), 40.

Bischoff-Mattson, Z., \& Lynch, A. H. (2017). Integrative Governance of Environmental Water in Australia’s Murray-Darling Basin: Evolving Challenges and Emerging Pathways. Environmental Management, 60(1), 41-56.

Bischoff-Mattson, Z., Lynch, A. H., \& Joachim, L. (2018). Justice, Science, or Collaboration: Divergent Perspectives on Indigenous Cultural Water in Australia's Murray-Darling Basin. Water Policy, 20(2), 235-251.

Blaser, M. (2014). Ontology and Indigeneity: On the Political Ontology of Heterogeneous Assemblages. Cultural Geographies, 21(1), 49-58.

Blaser, M., Briones, C., Burman, A., Escobar, A., Green, L., Holbraad, M., et al. (2013). Ontological Conflicts and the Stories of Peoples in Spite of Europe: Toward a Conversation on Political Ontology. Current Anthropology, 54(5), 547-568.

Blumm, M. C. (1988). Public Property and the Democratization of Western

Water Law: A Modern View of the Public Trust Doctrine. Environmental Law, 19, 573.

Brierley, G., Tadaki, M., Hikuroa, D., Blue, B., Šunde, C., Tunnicliffe, J., \& Salmond, A. (2019). A Geomorphic Perspective on the Rights of the River in Aotearoa New Zealand. River Research and Applications, 35(10), 1640-1651. https://doi.org/10.1002/rra.3343.

Bryan, M. (2017). Valuing Scared Tribal Waters Within Prior Appropriation. Natural Resources Journal, 57(6), 139-181.

Castleden, H., Hart, C., Cunsolo, A., Harper, S., \& Martin, D. (2017). Reconciliation and Relationality in Water Research and Management in 
Canada: Implementing Indigenous Ontologies, Epistemologies, and Methodologies. In S. Renzetti \& D. P. Dupont (Eds.), Water Policy and Governance in Canada (pp. 69-95). Cham: Springer International Publishing. Chandler, D., \& Reid, J. (2018). 'Being in Being': Contesting the Ontopolitics of Indigeneity. The European Legacy, 23(3), 251-268.

Charpleix, L. (2018). The Whanganui River as Te Awa Tupua: Place-Based Law in a Legally Pluralistic Society. The Geographical Journal, 184, 19-30.

Chuji, M., Rengifo, G., \& Gudynas, E. (2019). Buenvivir. Pluriverse-A PostDevelopment Dictionary, 1, 11-113.

Clark, C., Emmanouil, N., Page, J., \& Pelizzon, A. (2018). Can You Hear the Rivers Sing: Legal Personhood, Ontology, and the Nitty-Gritty of Governance. Ecology Law Quarterly, 45, 787.

Cochrane, R. (2014). Climate Change, Buen Vivir, and the Dialectic of Enlightenment: Toward a Feminist Critical Philosophy of Climate Justice. Hypatia, 29(3), 576-598.

Collins, T., \& Esterling, S. (2019). Fluid Personality: Indigenous Rights and the Te Awa Tupua (Whanganui River Claims Settlement) Act 2017 in Aotearoa New Zealand. Melbourne Journal of International Law, 20, 197.

Cosens, B., \& Chaffin, B. (2016). Adaptive Governance of Water Resources Shared with Indigenous Peoples: The Role of Law. Water, 8(3), 97.

Coulthard, G. S. (2014). Red Skin, White Masks: Rejecting the Colonial Politics of Recognition. University of Minnesota Press. Retrieved May 19, 2019, from https://muse.jhu.edu/book/35470.

Court of Appeal. Trans-tasman Resources Limited v Taranaki-Whanganui Conservation Board and Others [2020] NZCA 86, No. 86 (New Zealand Court of Appeal 2020).

Crow, S. K., Tipa, G. T., Booker, D. J., \& Nelson, K. D. (2018). Relationships Between Maori Values and Streamflow: Tools for Incorporating Cultural Values into Freshwater Management Decisions. New Zealand Journal of Marine and Freshwater Research, 52(4), 626-642.

Curley, A. (2019). "Our Winters' Rights": Challenging Colonial Water Laws. Global Environmental Politics, 19(3), 57-76.

Curran, D. (2019). Indigenous Processes of Consent: Repoliticizing Water Governance Through Legal Pluralism. Water, 11(3), 571.

Daigle, M. (2016). Awawanenitakik: The Spatial Politics of Recognition and Relational Geographies of Indigenous Self-Determination. The Canadian Geographer/Le Géographe Canadien, 60(2), 259-269.

Davies, M. (2010). Legal Pluralism. Oxford: Oxford University Press. 
Dorsett, S. (2017). Juridical Encounters: Maori and the Colonial Courts, 1840-1852. Auckland: Auckland University Press.

Dunford, R. (2020). Converging on Food Sovereignty: Transnational Peasant Activism, Pluriversality and Counter-Hegemony. Globalizations, 1-15. https://doi.org/10.1080/14747731.2020.1722494.

Durie, E. T. (1994). Custom Law: Address to the New Zealand Society for Legal and Social Philosophy. Victoria University of Wellington Law Review, 24, 325.

Durie, M. (2006). Measuring Māori Wellbeing. New Zealand Treasury Guest Lecture Series, 1.

Ede, K. C. (2002). He Kanawai Pono no ka Wai (A Just Law for Water): The Application and Implications of the Public Trust Doctrine In re Water Use Permit Applications. Ecology Law Quarterly, 29, 283.

Engle, K. (2011). On Fragile Architecture: The UN Declaration on the Rights of Indigenous Peoples in the Context of Human Rights. European Journal of International Law, 22(1), 141-163.

Forster, M. (2016). Indigenous-Environmental-Autonomy-in-Aotearoa-NewZealand. AlterNative: An International Journal of Indigenous Peoples, 12(3), 316-330.

Gilio-Whitaker, D. (2019). As Long as Grass Grows: The Indigenous Fight for Environmental Justice from Colonization to Standing Rock. Boston: Beacon Press.

Green, A., \& Hendry, J. (2019). Non-Positivist Legal Pluralism and Crises of Legitimacy in Settler-States. SSRN Scholarly Paper No. ID 3453251. Rochester, NY: Social Science Research Network. Retrieved June 15, 2020, from https://papers.ssrn.com/abstract=3453251.

Greensill, A. N. (2010). Inside the Resource Management Act: A Tainui Case Study. Thesis, The University of Waikato. Retrieved June 15, 2020, from https://researchcommons.waikato.ac.nz/handle/10289/4922.

Grosfoguel, R. (2015). Transmodernity, Border Thinking, and Global Coloniality. Nous, 13(9).

Harmsworth, G., Awatere, S., \& Robb, M. (2016). Indigenous Māori Values and Perspectives to Inform Freshwater Management in Aotearoa-New Zealand. Ecology and Society, 21(4), 9.

Harris, R., Tobias, M., Jeffreys, M., Waldegrave, K., Karlsen, S., \& Nazroo, J. (2006). Racism and Health: The Relationship Between Experience of Racial Discrimination and Health in New Zealand. Social Science \& Medicine, 63(6), 1428-1441. 
Healy, S., Huygens, I., \& Murphy, T. (2012). Ngapuhi Speaks: He Whakaputanga and Te Tiriti o Waitangi: Independent Report on Ngapubi Nui Tonu Claim. Te Kawariki \& Network Waitangi Whangarei.

Hendry, J. (2019). Margaret Davies: Law Unlimited: Materialism, Pluralism, and Legal Theory. Journal of Law and Society, 46(1), 169-173.

Hendry, J., \& Tatum, M. L. (2018). Justice for Native Nations: Insights from Legal Pluralism. Arizona Law Review, 60, 91.

Hickford, M. (2018). Reflecting on Landscapes of Obligation, Their Making and Tacit Constitutionalisation: Freshwater Claims, Proprietorship and "Stewardship". In B. Martin, L. T. Aho, \& M. Humphries-Kil (Eds.), ResponsAbility: Law and Governance for Living Well with the Earth (pp. 162-182). London: Routledge. https://doi.org/10.4324/9780429467622.

Howitt, R., \& Suchet-Pearson, S. (2006). Changing Country, Telling Stories: Research Ethics, Methods and Empowerment in Working with Aboriginal Women. In K. Lahiri-Dutta (Ed.), Fluid Bonds: Views on Gender and Water (pp. 48-63). New York: Springer.

Hunt, S. E. (2014, March 3). Witnessing the Colonialscape: Lighting the Intimate Fires of Indigenous Legal Pluralism. Thesis, Environment: Department of Geography. Retrieved June 9, 2019, from http://summit.sfu.ca/ item/14145\%23310.

Iwi Rep 6. (2020, February 14). Interview with Iwi Representative 6.

Jackson, M. (1992). The Treaty and the Word: The Colonization of Māori Philosophy. In G. Oddie \& R. W. Perrett (Eds.), Justice, Ethics, and New Zealand Society (pp. 1-10). Oxford: Oxford University Press. Retrieved July 14, 2017, from https://philpapers.org/rec/JACTTA-4.

Jackson, M. (1993). Land Loss and the Treaty of Waitangi. Te Ao Märama: Regaining Aotearoa. Mäori Writers Speak Out, 2.

Jackson, M. (1995). Justice and Political Power: Reasserting Maori Legal

Processes. In Legal Pluralism and the Colonial Legacy: Indigenous Experiences of Justice in Canada, Australia, and New Zealand (pp. 243-263). Aldershot: Averbury Ashgate.

Jackson, M. (2007). Globalisation and the Colonising State of Mind. In Resistance: An Indigenous Response to Neoliberalism (pp. 167-182). Wellington: Huia.

Jackson, S. (2018). Indigenous Peoples and Water Justice in a Globalizing World. In K. Conca \& E. Weinthal (Eds.), The Oxford Handbook of Water Politics and Policy. New York: Oxford University Press.

Johnston, A. (2018). Murky Waters: The Recognition of Maori Rights and Interests in Freshwater. Auckland University Law Review, 24, 39. 
Jones, C. (2016). New Treaty, New Tradition: Reconciling New Zealand and Maori Law. Toronto: University of British Columbia. Retrieved June 12, 2019, from https://books.google.co.nz/books?hl=en\&lr=\&id=DSLCDAAAQBAJ $\& o \mathrm{i}=\mathrm{fnd} \& \mathrm{pg}=\mathrm{PT} 5 \& \mathrm{dq}=\mathrm{Jones}+2016+\mathrm{New}+$ Treaty $\&$ ots $=09 \mathrm{dWY}$ $\mathrm{fMZ0} \&$ sig=vEDmsW4b2_KETAJpQfJWLcrDjRg\#v=onepage\&q=Jo nes $\% 202016 \% 20 \mathrm{New} \% 20$ Treaty\&f=false.

Kyle, M. (2013). The Four Great Waters Case: An Important Expansion of Waiahole Ditch and the Public Trust Doctrine. University of Denver Water Law Review, 17, 21.

Leonard, B., Parker, D. P., \& Anderson, T. L. (2020). Land Quality, Land Rights, and Indigenous Poverty. Journal of Development Economics, 143, 102435.

LeQuesne, T. (2019). Petro-Hegemony and the Matrix of Resistance: What Can Standing Rock's Water Protectors Teach Us About Organizing for Climate Justice in the United States? Environmental Sociology, 5(2), 188-206.

Maldonado-Torres, N. (2016). Colonialism, Neocolonial, Internal Colonialism, the Postcolonial, Coloniality, and Decoloniality. In Y. Martínez-San Miguel, S.-J. Ben, \& M. Belausteguigoitia (Eds.), Critical Terms in Caribbean and Latin American Thought: Historical and Institutional Trajectories (pp. 67-78). New York: Palgrave Macmillan.

Mascarenhas, M. (2007). Where the Waters Divide: First Nations, Tainted Water and Environmental Justice in Canada. Local Environment, 12(6), 565-577.

McGregor, D. (2018). Mino-Mnaamodzawin: Achieving Indigenous Environmental Justice in Canada. Environment and Society, 9(1), 7-24.

McGregor, D., Whitaker, S., \& Sritharan, M. (2020). Indigenous Environmental Justice and Sustainability. Current Opinion in Environmental Sustainability, 43, 35-40.

Memon, P. A., \& Kirk, N. (2012). Role of Indigenous Māori People in Collaborative Water Governance in Aotearoa/New Zealand. Journal of Environmental Planning and Management, 55(7), 941-959.

Metge, J. (1997). Commentary on Judge Durie's Custom Law. Custom Law Guidelines Project Paper. Unpublished.

Mikaere, A. (2005). Cultural Invasion Continued: The Ongoing Colonisation of Tikanga Maori. Yearbook of New Zealand Jurisprudence, 8(2), 134.

Mikaere, A. (2011). Colonising Myths-Maori Realities: He Rukuruku Whakaaro. Wellington: Huia Publishers. 
Morris, J. D. K., \& Ruru, J. (2010). Giving Voice to Rivers: Legal Personality as Recognising Indigenous Peoples' Relationships to Water? Australian Indigenous Law Review, 14(2), 49-62.

Muir, B. R., \& Booth, A. L. (2012). An Environmental Justice Analysis of Caribou Recovery Planning, Protection of an Indigenous Culture, and Coal Mining Development in Northeast British Columbia, Canada. Environment, Development and Sustainability, 14(4), 455-476.

Mulgan, R. (1997). Commentary on Chief Judge Durie's Custom Law Paper from the Perspective of a Pakeha Political Scientist. Paper, Law Commission. Unpublished.

Muller, S., Hemming, S., \& Rigney, D. (2019). Indigenous Sovereignties: Relational Ontologies and Environmental Management. Geographical Research, 57(4), 399-410.

Muru-Lanning, M. (2012). Māori Research Collaborations, Mātauranga Māori Science and the Appropriation of Water in New Zealand. Anthropological Forum, 22(2), 151-164.

Muru-Lanning, M. (2016a). Tupuna Awa: People and Politics of the Waikato River. Auckland: Auckland University Press.

Muru-Lanning, M. (2016b). Intergenerational Investments or Selling Ancestors? Māori Perspectives of Privatising New Zealand Electricity-Generating Assets. In P. Adds, B. Bönisch-Brednich, R. S. Hill, \& G. Whimp (Eds.), Reconciliation, Representation and Indigeneity: 'Biculturalism' in Aotearoa New Zealand (pp. 49-64). Heidelberg: Universiatsverlag Winter Heidelberg.

Mutu, M. (2011). The State of Maori Rights. Wellington: Huia Publishers.

Mutu, M. (2018). Behind the Smoke and Mirrors of the Treaty of Waitangi Claims Settlement Process in New Zealand: No Prospect for Justice and Reconciliation for Māori Without Constitutional Transformation. Journal of Global Ethics, 14(2), 208-221. https://doi.org/10.108 0/17449626.2018.1507003.

Mutu, M. (2019). The Treaty Claims Settlement Process in New Zealand and Its Impact on Māori. Land, 8(10), 152. https://doi.org/10.3390/land8100152. New Zealand Parliament. Treaty of Waitangi Act 1975. (1975). http://www. legislation.govt.nz/act/public/1975/0114/latest/DLM435515.html? search=qs_act $\% 40$ bill\%40regulation\%40deemedreg_Tuhoe+Settlement_ resel_25_h\&p=1\&sr=1. Accessed 3 July 2019.

New Zealand Parliament. Resource Management Act (1991). http://www.legislation.govt.nz/act/public/1991/0069/223.0/DLM230265.html 
New Zealand Parliament. Ngāi Tahu Claims Settlement Act., Pub. L. No. No 97 (1998). http://www.legislation.govt.nz/act/public/1998/0097/latest/ DLM429090.html. Accessed 5 July 2020.

New Zealand Parliament. Ngā Wai o Maniapoto (Waipā River) Act (2012). Retrieved April 19, 2020, from http://www.legislation.govt.nz/act/public/2012/0029/latest/DLM3335204.html.

New Zealand Parliament. Te Urewera Act 2014 (2014). Retrieved July 3, 2019, from http://www.legislation.govt.nz/act/public/2014/0051/latest/ DLM6183601.html?search=qs_act\%40bill\%40regulation\%40deemed reg_Tuhoe+Settlement_resel_25_h\&p=1\&sr=1.

New Zealand Parliament. Te Awa Tupua (Whanganui River Claims Settlement) Act (2017). Retrieved April 19, 2020, from http://www.legislation.govt.nz/ act/public/2017/0007/latest/whole.html.

New Zealand Supreme Court. Takamore v Clarke. 733 NZLR (NZSC 2013).

Ngāti Maniapoto, Maniapoto Maori Trust Board, \& Sovereign by Right of New Zealand. (2010, September 27). Waiwaia Accord. Unpublished.

Nursey-Bray, M., \& Palmer, R. (2018). Country, Climate Change Adaptation and Colonisation: Insights from an Indigenous Adaptation Planning Process, Australia. Heliyon, 4(3), e00565.

O'Donnell, E. L. (2018). At the Intersection of the Sacred and the Legal: Rights for Nature in Uttarakhand, India. Journal of Environmental Law, 30(1), 135-144.

O’Donnell, E., \& Macpherson, E. (2019). Voice, Power and Legitimacy: The Role of the Legal Person in River Management in New Zealand, Chile and Australia. Australasian Journal of Water Resources, 23(1), 35-44.

O’Donnell, E., \& Talbot-Jones, J. (2018). Creating Legal Rights for Rivers: Lessons from Australia, New Zealand, and India. Ecology and Society, 23(1), 7. Orange, C. (2015). The Treaty of Waitangi. Wellington: Bridget Williams Books. Oslender, U. (2019). Geographies of the Pluriverse: Decolonial Thinking and Ontological Conflict on Colombia's Pacific Coast. Annals of the American Association of Geographers, 109(6), 1691-1705.

Palmer, G. (1989). The Treaty of Waitangi - Principles for Crown Action. Victoria University of Wellington Law Review, 19, 335.

Papacostas, C. S. (2014). Traditional Water Rights, Ecology and the Public Trust Doctrine in Hawaii. Water Policy, 16(1), 184-196.

Parsons, M., Nalau, J., Fisher, K., \& Brown, C. (2019). Disrupting Path Dependency: Making Room for Indigenous Knowledge in River Management. Global Environmental Change, 56, 95-113. 
Premauer, J. M., \& Berkes, F. (2015). A Pluralistic Approach to Protected Area Governance: Indigenous Peoples and Makuira National Park, Colombia. Ethnobiology and Conservation, 4.

Prendergast, J. Wi Parata v The Bishop of Wellington (1877). 1 NZLRLC 14 (17 October 1877) 3 NZJurRp (NS) 72 (SC) (Supreme Court Wellington 1877). Retrieved June 5, 2019, from http://www.nzlii.org/cgi-bin/sinodisp/ nz/cases/NZJurRp/1877/183.html?query=title(Wi\%20Parata\%20near\%20 Bishop\%20of\%20Wellington.

Rangitāiki River Forum. (2015). Te Ara Whanui o Rangitāiki - Pathways of the Rangitaiki. Bay of Plenty Regional Council.

Robinson, D. F., \& Graham, N. (2018). Legal Pluralisms, Justice and Spatial Conflicts: New Directions in Legal Geography. The Geographical Journal, 184(1), 3-7.

Rose, D. B. (2004). Reports from a Wild Country: Ethics for Decolonisation. UNSW Press.

Ruru, J. (2009). The Common Law Doctrine of Native Title Possibilities for Freshwater. In Indigenous Legal Water Forum, Dunedin (Vol. 27).

Ruru, J. (2012). The Right to Water as the Right to Identity: Legal Struggles of Indigenous Peoples of Aotearoa New Zealand. In F. Sultana \& A. Loftus (Eds.), The Right to Water: Politics, Governance and Social Struggle (pp. 110-122). New York: Routledge.

Ruru, J. (2013). The Right to Water as the Right to Identity: Legal Struggles of Indigenous Peoples of Aotearoa New Zealand. In The Right to Water: Politics, Governance and Social Struggles. New York: Earthscan.

Ruru, J. (2018a). Listening to Papatūānuku: A Call to Reform Water Law. Journal of the Royal Society of New Zealand, 48(2-3), 215-224.

Ruru, J. (2018b). First Laws: Tikanga Maori in/and the Law. Victoria University of Wellington Law Review, 49, 211.

Ruru, J., Borrows, J., \& Coyle, M. (2017). A Treaty in Another Context: Creating Reimagined Treaty Relationships in Aotearoa New Zealand. Toronto: University of Toronto Press.

Salmond, A. (2017). Tears of Rangi: Experiments Across Worlds. Auckland: Auckland University Press.

Salmond, D. A. (2018). Rivers as Ancestors and Other Realities: Governance of Waterways in Aotearoa/New Zealand. In ResponsAbility (pp. 183-192). Routledge.

Salmond, A., Tadaki, M., \& Gregory, T. (2014). Enacting New Freshwater Geographies: Te Awaroa and the Transformative Imagination. New Zealand Geographical Society, 70(1), 47-55. https://doi.org/10.1111/nzg.12039. 
Salmond, A., Brierley, G., \& Hikuroa, D. (2019). Let the Rivers Speak. Policy Quarterly, 15(3). https://doi.org/10.26686/pq.v15i3.5687.

Samuel, S. (2019). Witsaja iki, or the Good Life in Ecuadorian Amazonia: Knowledge co-Production for Climate Resilience. International Labour Organization. Retrieved June 10, 2020, from https://cgspace.cgiar.org/ handle/10568/105603.

Shah, S. H., \& Rodina, L. (2018). Water Ethics, Justice, and Equity in SocialEcological Systems Conservation: Lessons from the Queensland Wild Rivers Act. Water Policy; Oxford, 20(5), 933-952.

Sieder, R., \& Barrera, A. (2017). Women and Legal Pluralism: Lessons from Indigenous Governance Systems in the Andes. Journal of Latin American Studies, 49, 633-658.

Smith, L. T. (2013). Decolonizing Methodologies: Research and Indigenous Peoples. New York: Zed Books.

Stephenson, J. (2001). Recognising Rangatiratanga in Resource Management for Maori Land: A Need for a New Set of Arrangements. New Zealand Journal of Environmental Law, 5, 159.

Strang, V. (2014). The Taniwha and the Crown: Defending Water Rights in Aotearoa/New Zealand: Defending Water Rights in Aotearoa/New Zealand. Wiley Interdisciplinary Reviews: Water, 1(1), 121-131.

Te Aho, L. (2019). Te Mana o te Wai: An Indigenous Perspective on Rivers and River Management. River Research and Applications, 35(10), 1615-1621.

Thompson-Fawcett, M., Ruru, J., \& Tipa, G. (2017). Indigenous Resource Management Plans: Transporting Non-Indigenous People into the Indigenous World. Planning Practice \& Research, 32(3), 259-273.

Tobias, J. K., \& Richmond, C. A. M. (2014). "That Land Means Everything To Us as Anishinaabe...": Environmental Dispossession and Resilience on the North Shore of Lake Superior. Health \& Place, 29, 26-33.

Todd, Z. (2014). Fish Pluralities: Human-Animal Relations and Sites of Engagement in Paulatuuq, Arctic Canada. Études/Inuit/Studies, 38(1-2), 217-238.

Todd, Z. (2016). An Indigenous Feminist's Take on the Ontological Turn: 'Ontology' Is Just Another Word for Colonialism. Journal of Historical Sociology, 29(1), 4-22.

Vickery, J., \& Hunter, L. M. (2016). Native Americans: Where in Environmental Justice Research? Society \& Natural Resources, 29(1), 36-52.

Waikato River Authority. (2016). Waikato River Authority Annual Report 2016. Waitangi Tribunal. (1983). Report of the Waitangi Tribunal on the MotunuiWaitara Claim (Waitangi Tribunal). Wellington: Department of Justice. 
Waitangi Tribunal. (1999). The Whanganui River Report (Wai 167). Wellington: Legislation Direct.

Waitangi Tribunal. (2009). Urewera Report-Part I. Wellington: Legislation Direct.

Waitangi Tribunal. (2018). Te Mana Whatu Ahuru: Report on Te Rohe Pōtae Claims Pre-Publication Version Parts I and II. Wellington: Unpublished.

Walker, R. (1996). Nga pepa a Ranginui (The Walker Papers). Auckland: Penguin Group.

Walker, R., \& McIntosh, T. (2017). Kāwanatanga, Tino Rangatiratanga and the Constitution. In New Zealand and the World (Vol. 1, pp. 201-219). World Scientific. https://doi.org/10.1142/9789813232402_0013.

Watene, K. (2016). Valuing Nature: Māori Philosophy and the Capability Approach. Oxford Development Studies, 44(3), 287-296.

Watts, V. (2013). Indigenous Place-Thought and Agency Amongst Humans and Non Humans (First Woman and Sky Woman Go on a European World Tour!). Decolonization: Indigeneity, Education \& Society, 2(1) Retrieved May 16, 2020, from https://jps.library.utoronto.ca/index.php/des/article/ view/19145.

Weir, J. K. (2009). Murray River Country: An Ecological Dialogue with Traditional Owners. Aboriginal Studies Press.

Whaanga, H., Wehi, P., Cox, M., Roa, T., \& Kusabs, I. (2018). Māori Oral Traditions Record and Convey Indigenous Knowledge of Marine and Freshwater Resources. New Zealand Journal of Marine and Freshwater Research, 52(4), 487-496.

Wheen, N. R., \& Hayward, J. (2012). Treaty of Waitangi Settlements. Wellington: Bridget Williams Books.

Whyte, K. P. (2011). The Recognition Dimensions of Environmental Justice in Indian Country. Environmental Justice, 4(4), 199-205.

Whyte, K. P. (2017). The Dakota Access Pipeline, Environmental Injustice, and U.S. Colonialism. Red Ink: An International Journal of Indigenous Literature, Arts, \& Humanities, 19(1) Retrieved May 29, 2020, from https://ssrn.com/ abstract $=2925513$.

Whyte, K. P. (2018). Settler Colonialism, Ecology, and Environmental Injustice. Environment and Society, 9(1), 125-144. https://doi.org/10.3167/ ares.2018.090109.

Wildcat, D. R. (2013). Introduction: Climate Change and Indigenous Peoples of the USA. Climatic Change, 120(3), 509-515.

Williams, E. K., Watene-Rawiri, E. M., \& Tipa, G. T. (2018). Empowering Indigenous Community Engagement and Approaches in Lake Restoration: 
An Āotearoa-New Zealand Perspective. In Lake Restoration Handbook (pp. 495-531). New York: Springer.

Wilson, N. J. (2019). “Seeing Water Like a State?”: Indigenous Water Governance Through Yukon First Nation Self-Government Agreements. Geoforum, 104, 101-113.

Wilson, N. J. (2020). Querying Water Co-Governance: Yukon First Nations and Water Governance in the Context of Modern Land Claim Agreements. Water Alternatives; Montpellier, 13(1), 93-118.

Wilson, N. J., \& Inkster, J. (2018). Respecting Water: Indigenous Water Governance, Ontologies, and the Politics of Kinship on the Ground. Environment and Planning E: Nature and Space, 1(4), 516-538.

Winter, C. J. (2018). The Paralysis of Intergenerational Justice: Decolonising Entangled Futures. Retrieved January 11, 2020, from https://ses.library.usyd. edu.au/handle/2123/18009.

Winter, C. J. (2019). Does Time Colonise Intergenerational Environmental Justice Theory? Environmental Politics, 1-19. https://doi.org/10.108 0/09644016.2019.1569745.

Yates, J. S., Harris, L. M., \& Wilson, N. J. (2017). Multiple Ontologies of Water: Politics, Conflict and Implications for Governance. Environmental Planning D: Society and Space, 35(5), 797-815.

Youatt, R. (2017). Personhood and the Rights of Nature: The New Subjects of Contemporary Earth Politics. International Political Sociology, 11, 39-54.

Zwarteveen, M. Z., \& Boelens, R. (2014). Defining, Researching and Struggling for Water Justice: Some Conceptual Building Blocks for Research and Action. Water International, 39(2), 143-158. 
Open Access This chapter is licensed under the terms of the Creative Commons Attribution 4.0 International License (http://creativecommons.org/licenses/ by/4.0/), which permits use, sharing, adaptation, distribution and reproduction in any medium or format, as long as you give appropriate credit to the original author(s) and the source, provide a link to the Creative Commons licence and indicate if changes were made.

The images or other third party material in this chapter are included in the chapter's Creative Commons licence, unless indicated otherwise in a credit line to the material. If material is not included in the chapter's Creative Commons licence and your intended use is not permitted by statutory regulation or exceeds the permitted use, you will need to obtain permission directly from the copyright holder.

(c) (i) 